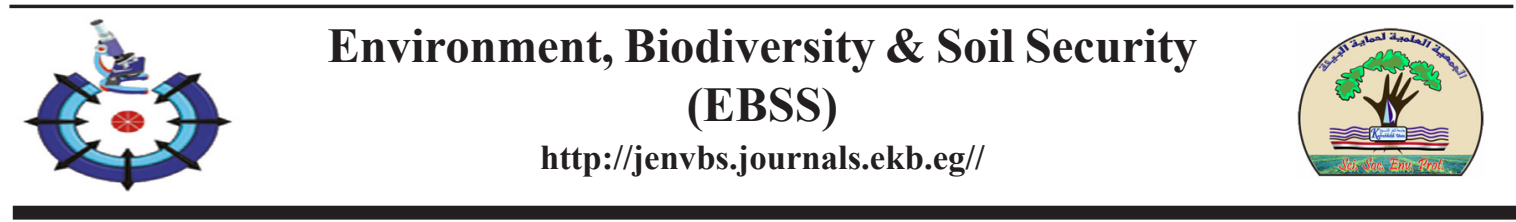

\title{
Phytoplasma-Induced Biochemical and Genetic Variations in Crassula argentea
}

Mayada K. Seliem

Ornamental and Floriculture Department, Horticulture Research Institute, Antoniades, Alexandria 21599, Egypt

\begin{abstract}
DHYTOPLASMA is plant pathogenic bacteria that causes several morphological abnormalities. This study reported on biochemical and genetic variability between the phytoplasma infected (PI) and symptomless Crassula argentea plants using RAPD markers. Chemical composition of normal plants was higher of all elements. However, change in ferrous $(\mathrm{Fe})$ content was not significant between normal and abnormal plants. Infected plants had potassium content higher than normal plant. Also, chlorophyll contents decreased by phytoplasma infection. Water content was higher in infected plant than normal plant. The electrophoresis of studied plants had a high level of polymorphism. There were polymorphism percentage (32.8) between PI and symptomless plants depend on 67 amplified bands. The primers OPC10, OPK05 and OPU05 resulted in various polymorphic banding patterns that were unparalleled to every primer and identifiable over the PI and symptomless plants. RAPD molecular marker analysis revealed epigenetic variations between normal and phytoplasma infected plants, and it could be utilized for the identification of Crassula genotypes.
\end{abstract}

Keywords: Fasciation, RAPD, Polymorphism, Succulent, Elements.

\section{Introduction}

Crassula argentea,Crassulaceae, is an evergreen plant has thick branches and smooth, rounded, succulent leaves that grow in across opposite position. The plant is native to South Africa. It stores the water in fleshy leaves (Morandini and Salamini, 2003). Besides using the jade plant as a house plant worldwide (GRIN 2015), it is used as antimicrobial and medicinal plant (Eggli 2002; Morandini and Salamini, 2003).

There are little studies on biochemical and physiological effect of phytoplasma on plants. The previous reports showed that infection by phytoplasma had the major effect on the level of some biochemical in plant tissues. Chang (1977) observed during plant growth that phytoplasma infection of Catharanthus roseus alter in chlorophyll synthesis. In addition, infected maize by mollicutes had lower chemical composition than normal plants (Oliveira et al. 2002). Zafari et al. (2012) showed that phytoplasma infection induced alteration in some biochemical compound and physiological traits in Citrus aurantifolia leaves.

Phytoplasmas belong to the class Mollicutes, a group of wall-less Gram-positive bacteria. They are plant pathogenic bacteria infect numerous plant species in the world (Lee et al. 2000). The relationships between phytoplasmas and their hosts are obligate symbiotic; they are intracellular parasites (Hogenhout et al. 2008). Phytoplasmas use their secreted proteins to be able to interact directly with host cells (MacLean et al. 2011). Phytoplasmas could be characterized also as lacking cell wall and pleomorphic form as well as plant pathogenic bacteria induced several diseases of different plants in worldwide (Hemmati et al. 2021).

Phytoplasmas infection of succulent plants are developing distinctive symptoms such as abnormal growth and fasciation (Omar et al. 2014; Dewir, 2016). Because of special appearance

Corresponding author: E-mail: mayadaseliem@gmail.com

Received: 18/3/2021; Accepted:12/4/2021

DOI: $10.21608 /$ jenvbs.2021.68434.1129

C2021 National Information and Documentation Center (NIDOC) 
and the great value of abnormal plants, they have been grown and produced to other parts of worldwide as ornamentals. In addition, abnormal succulent plants have economic value for their using as ornamental pot plants (Dewir, 2016) however; abnormal plants can be source of phytoplasma infection for numerous crops (Omar et al. 2008). Symptoms of yellowing, witches' broom (axillary buds proliferation), phyllody, virescence, abnormal elongation of internodes, stunted growth (dwarfing) and irregular leaf and flower growth, are associated with infections by various phytoplasmas (Lee et al. 2000; Duduk and Bertaccini 2006; Bertaccini and Duduk 2009; Omar and Foissac 2012; Bertacciniet al. 2014; Dewir et al. 2015). Cacti and succulent plants infected by phytoplasma are resulting in typical symptoms such as witches' broom, fasciation and abnormal plant growth. These fascinating species have attractive appearances, which impact their economic value. Therefore, they have been cultivated and spread worldwide as ornamentals, but many reports confirmed that infected cacti and succulent plants are phytoplasma-host and thus can transmit infection to other plant species (Granata and Sidoti, 2002; Granata et al. 2006; Weintraub and Beanland, 2006; Bertaccini et al. 2007; Wei et al. 2007; Cai et al. 2008; Omar et al. 2008; 2014; Zak et al. 2006; Li et al. 2012; Dewir et al. 2015; 2016). Witches' broom, yellowing, leaf shape abnormalities, fasciation, stunted growth and late flowering were common reported symptoms of phytoplasma infection in cacti and succulent plant species. Collectors and horticulturists are researching on fasciated plantas real living sculptures. Therefore, the prices of phytoplasma-infected cacti can reach ten folds over non-infected species (Dewir et al. 2016).

Randomly amplified polymorphic DNA (RAPD) is one of various molecular techniques used for estimation of genetic variations based upon information at the DNA level. Therefore, RAPD marker is more used since 1990's to evaluate genetic variation at the DNA level based on polymerase chain reaction (PCR) (Welsh and McClellan, 1990). RAPD is using a single arbitrary primer in PCR, producing in amplification of many-separated DNA. This technique is an efficient and quick method for testing DNA sequence depend on polymorphism at a huge number of loci. The best merit of RAPD marker does not require pre-sequencing of DNA. The wide range of possibility primers that can be used, give the technique considerable diagnostic power.
Conscious selection of primers can be helping in reproducible RAPD bands. There are different purposes of RAPD analysis such as identification and classification of genotypes (Fukuoka et al. 1992), breeds identification (Qian et al., 1996) and analysis of genetic diversity (Yu and Paul 1992; Mackill 1995; Cao and Oard, 1997). The great advent of RAPD provides an easy tool for the molecular geneticist (Williams et al. 1990).

In the previous report, identified fasciation phytoplasmas in Crassula argentea (The accession number of phytoplasma in Gene Bank was HG421074). Genetic analysis potted the fasciation phytoplasma in the group of 16SrII-D (Dewir et al. 2016). The aims of this study were the determination of the changes in biochemical and water content of normal and abnormal plants, also, using RAPD molecular marker for the detection of genetic variations in phytoplasma infected plants.

\section{Materials and Methods}

\section{Plant materials and experiment location}

Normal (symptomless leaves) and abnormal (Phytoplasma infected) plants of Crassula argentea were used as plant material in this research (Fig. 1). The studied plants were grown at a local nursery located in El-Gharbia Governorate, Egypt under a 50\% shade net greenhouse. Plants were cultured in a medium consist of mixture of clay: sand $(1: 1, v / v)$ at clay pots $(20 \mathrm{~cm}$ diameter). Plants were irrigated when need nearly once a month during the winter season and once a week during the summer season. Compound fertilizer (19: 19: 19; $\mathrm{NH}_{4} \mathrm{NO}_{3}: \mathrm{P}_{2} \mathrm{O}_{5}: \mathrm{KNO}_{3}$ ) were used in fertilizing $C$. argentea plants once a month with rate of $1 \mathrm{gL}^{-1}$. The studied plants were growing near to Petunia hybrid beds that were infected by phytoplasma. About 140 plants had fasciation symptoms from 500 Crassula plants with the percentage 28\% (Dewir et al. 2016). All analyses in this study were carried out in Physiology and Breeding of Horticultural Crops Laboratory, Kafrelsheikh University during two years (2017 and 2018).

\section{Determination of chlorophyll}

The amount of chlorophyll-a (Chl a) andchlorophyll-b (Chl b) in the fifth leave from the shoot tip were determined by spectrophotometric analysis of normal and abnormal (infected) plants. Chlorophyll was extracted from $1 \mathrm{~g}$ leaf tissue by adding $5 \mathrm{~mL}$ dimethylformamide and incubated in the dark for $48 \mathrm{hr}$. The absorbance was measured at 470, 647 and 663 nmusing anultraviolet160Aspectrophotometer (Shimadzu, Japan). 
Chlorophyll concentration was calculated from the spectrophotometric data using the formulae of Moran and Porath (1982). There were three replicates within each treatment.

\section{Determination of water content}

Total water content percentage was determined in normal and abnormal plants. Fifty gram from fresh weight was dried for $48 \mathrm{hr}$ at $80{ }^{\circ} \mathrm{C}$. Water content percentage was reported as the percentage of fresh weight.

\section{Chemical composition}

Leaves and stem samples of $C$. argentea were dried in oven at $70^{\circ}$ for $24 \mathrm{hr}$. Dried samples were grinded in a metal-free mill (IKaWerke, M 20 Germany) to obtain a homogenous powder. Powder sample (0.2 g) was mixed with concentrated sulfuric acid $(95 \%, 5 \mathrm{~mL})$, the mixture was heated on a sand hot plate for $10 \mathrm{~min}$. After that, perchloric acid $(0.5 \mathrm{~mL})$ was added with heating to obtain a clear solution. After cooling, the solution was filtered and diluted to $50 \mathrm{~mL}$ with distilled water (Evenhuis and de Waard, 1980). Nitrogen (mg kg-1 dry weight) was detected using a modified micro-Kjeldahl method as described by Chemists and Horwitz (1990). Phosphorus (mg kg-1dry weight) was detected according to Murphy and Riley (1962) and measured by colorimetrically in a spectrophotometer (GT 80+, UK). Potassium (mg kg-1 dry weight) was detected using an atomic absorption spectrophotometer (Avanta E; GBC, Victoria, Australia) according to Jones et al. (1991). $\mathrm{Ca}^{2+}$ and $\mathrm{Mg}^{2+}$ were extracted according to USAD (2004) and estimated using atomic absorption spectrometry method. The Mn, $\mathrm{Zn}$ and $\mathrm{Cu}$ concentration were detected using atomic absorption spectrophotometry (Avanta E; GBC) according to Jones et al. (1991).

\section{Sampling of plant material and DNA extraction}

The phytoplasma induced fasciation symptoms were visible through year. Three plants of fasciated and symptomless were randomly selected as a source of sampling. Cetyltrimethyl Ammonium Bromide (CTAB) was used of DNA extract according to Doyle and Doyle (1990). At first, liquid nitrogen was used for grounding external green parts of leaves to fine powder inmortar and pestle. After that, 800ul of $3 \%$ CTAB extraction buffer was added, vortexed for $20 \mathrm{sec}$ followed by heating at $60^{\circ} \mathrm{C}$ for $40 \mathrm{~min}$. Chloroform; Isoamylalcohol (24:1) were added to precipitate polysaccharides and proteins. The mix was centrifuged at $12000 \mathrm{rpm}$ for $10 \mathrm{~min}$. Then, supernatant was relocated to a clean Eppendorf tube and adding isopropanol at two third volume. After centrifugation at $12000 \mathrm{rpm}$ for ten min., the DNA pellets were resolved in TE buffer containing RNase and stored for $30 \mathrm{~min}$ at $37^{\circ} \mathrm{C}$, then $100 \mu \mathrm{l}$ of $7.5 \mathrm{M}$ ammonium acetate and $750 \mu \mathrm{l}$ of Ethanol were added. The DNA pellet were collected again by centrifugation and resolved in TE Buffer.

\section{PCR-RAPD analysis}

Six random decamer primer (Operon Technologies Inc, USA) were used for this study (Table 2). The reaction of PCR was done in $20 \mu \mathrm{l}$ volume containing genomic DNA at $2.0 \mathrm{ul}, 0.11 \mu \mathrm{l}$ of Dream taq DNA polymerase (5U), $2.0 \mu$ ldNTP's $(10 \mathrm{mM}), 2.0 \mu \mathrm{l}$ of $10 \times$ PCR DreanTaq green buffer and $1.5 \mu \mathrm{l}$ random primers (10 pMole). The amplification was carried out by an Eppendorf Mastercycler ep384 (Eppendorf, Germany). The program treated the mixture to $95^{\circ} \mathrm{C}$ for $5 \mathrm{~min}$ followed by 40 cycles as follows: denaturation at $95^{\circ} \mathrm{C}$ for one min, annealing $37^{\circ} \mathrm{C}$ for $30 \mathrm{sec}$, and polymerization at $72^{\circ} \mathrm{C}$ for $3 \mathrm{~min}$ and 7 min for final extension at $72^{\circ} \mathrm{C}$. PCR products were detected on a $1.5 \%$ agarose gel, visualized by ethidium bromide and photographed under Documentation system (UVITEC CAMBRIDGE Company, Cambridge, UK). Reproducibility of the DNA profiles was tested by repeating the clear and intense bands, which were scored while faint bands against background smear were not considered for the further analysis.

\section{Statistical analyses}

All samples were collected in a completely randomize in three replicates. The means and ANOVA were calculated using SPSS (version20) statistical software. All the obtained data of this study were statistically analyzed using Duncan's Multiple Range Test for comparing means of different treatments according to Snedecor and Cochran (1990) and significance was determined at $\mathrm{p} \leq 0.05$. My Image Analysis v2.0 software, Thermo scientific was used for analyzing RAPD profiles.

\section{Results and Discussion}

\section{Chlorophyll contents}

The chlorophyll content $\mathrm{a}$ and $\mathrm{b}$ in normal and abnormal plants of Crassula argentea had a significant difference (Fig. 2A). The most important results regarding chlorophyll content included that the Chla and b content were higher in case of normal plants compared to the abnormal ones. The $\mathrm{Chl}$ a content also was higher than $\mathrm{Chl}$ $\mathrm{b}$ in both normal and abnormal plants. It could 
be noticed that $\mathrm{Chl} a$ and $\mathrm{b}$ content were higher in normal plants compared to abnormal due to phytoplasma, which already had decreased both chlorophyll and other nutrients in abnormal plant that infected by phytoplasma. The same result observed by Rasool et al. (2020) that chlorophyll a, b and total chlorophyll contents were significantly reduced in phytoplasma-infected Citrus sinenses. Previous studies indicated that pigment content analysis was drastically reduced of total chlorophyll and carotenoid in infected leaves (Zafari et al. 2012). Also, difficultly uptake and transport of inorganic ions in abnormal plants can cause of yellowing leaves ( $\mathrm{Ji}$ et al. 2009). Most of these ions are important for biochemical synthesis such as chlorophyll. The reduction in the content of chlorophylls and auxin showed that the phytoplasma could interfere in photosynthesis and induced damaging in the leaf (Zafari et al. 2012). Previously reported showed thaphytoplasma infection altered theultrastructure of chloroplasts, causing disorganization of thylakoids (Pagliari et al. 2016; Xue et al. 2018). Data showed that phytoplasma had asignificant effect on water content of Crassula argentea (Fig. 2B). Infected plant had higher water content $(94.07 \%)$ than uninfected plant (92.05\%). El-Banna et al. (2013) found that the relative water content was influenced by fasciation in Opuntiacylindrica.

\section{Effect of phytoplasma infection on chemical composition}

Based on the chemical composition of normal and abnormal plants, the concentration of all studied nutrients was significantly differed compared to the normal plants except the nutrient of iron (Table 1). This trend could be observed in case of elements $\mathrm{N}, \mathrm{P}, \mathrm{K}, \mathrm{Ca}, \mathrm{Mg}, \mathrm{Mn}, \mathrm{Zn}$ and $\mathrm{Cu}$, which were higher in normal plants compared to abnormal due to phytoplasma. The highest values in these nutrients could be ordered as follows $\mathrm{Ca}$ $>\mathrm{Mg}>\mathrm{N}>\mathrm{K}>\mathrm{P}>\mathrm{Zn}>\mathrm{Mn}>\mathrm{F}>\mathrm{Cu}$. The only strange result recorded an incase of $\mathrm{K}$, which abnormal plants contained higher $\left(9.03 \mathrm{~g} \mathrm{~kg}^{-1}\right)$ compared to normal plant $\left(6.52 \mathrm{~g} \mathrm{~kg}^{-1}\right)$. It is clear that the responses of host plants to phytoplasma infection are complex and differ among plants (Rasool et al. 2020). Infected plant by phytoplasmas suffer strong disturbances that could have negative effect on phloem (Pagliari et al., 2016). The disturbance in phloem sieve elements resulted in negative effect on nutrition components uptake of infected plants. Several studies observed that K nutrient was higher in phytoplasms-infected plants than normal plant for its important of both pathogens and insects (Amtmann et al. 2008; Pradit et al. 2019). The highest values of nutrients were belonged $\mathrm{Ca}$, which reached to 36.5 and $24.7 \mathrm{~g}$ $\mathrm{kg}-1$ for normal and abnormal plants, respectively. There is no significant differences in Fe content of normal and abnormal plants. Buoso et al. (2019) observed that phytoplasma infection accumulate Fe from the phloem, converting the phloem into a sink tissue for Fe causing Fe starvation of plant.

Effect of phytoplasma infection on Genetic fidelity

The morphological symptoms of phytoplasma infection in Crassula argentea have been described as fasciation of leaves (Dewir et al., 2016). Infected plants by phytoplasma had clearly visible morphological differences when compared with normal plants. Normal plant of Crassula argentea had a uniform oval form (Fig. 1 A, B) while abnormal leaves had a horn bell form (Fig. 1 C, D). Many of fasciated cacti and succulent species with irregular shapes have been reported (El-Banna et al. 2013; Omar el al. 2014; Dewir 2016). RAPD primers produced 67 scorable markers among studied genotypes, out which 22 bands $(32.8 \%)$ were polymorphic (Table 2). Amplified products size ranged from $2508.4 \mathrm{bp}$ to $228.4 \mathrm{bp}$. Scorable markers number observed per primer extended from 8 to 15 . Among the primers used, OPU05 gave the highest bands number (15), while primer OPC10 had the lowest bands number (8). Primers OPD12 and OPQ14 produced monomorphic bands while primers OPC04, OPC10, OPK05 and OPU05 produced 22 polymorphic RAPD markers. The obtained markers achieved unique bands for a given genotype. The primer OPC04 gave fragments of 2000.7 and $1673.3 \mathrm{pb}$ specific for the symptomless and fragments of 1763.6 and 1565.6 specific for the abnormal plant. while Primers OPC10 and OPK05 gave specific bands belonged only to the genotype A. Primer OPU05 produced the highest number of specific bands, three bands of molecular sizes 2230.6,1572.4 and $1035.9 \mathrm{pb}$ were found only in genotype A whereas 10 specific bands ranged from 2133.7 to $265.5 \mathrm{pb}$ were found to be specific for the abnormal plant (Table 3 ). These primers could be clearly differentiating between the phytoplasma infected and symptomless Crassula plants (Fig. $3)$. For estimating genetic diversity, markerassisted selection in plant and animal breeding, genetic fingerprinting, and facilitating the mapbased cloning of genes, DNA markers could be important for these (Tankesly1995). RAPD technique is considered ideal to characterize, identify and estimate genetic diversity of many plant species (Isenegger et al. 2001; Spooner et al. 2005; Pervaiz et al. 2010). The diversity in bands number resulted by different primers affected by many factors such as template quantity, primer structure and minimal number of annealing sites in the genome. 
A previous study on Opuntia cylindrica showed variations in symptomless and fasciated tissues based on SDS-PAGE protein and randomly amplified polymorphic DNA analysis indicating possible epigenetic mutation of tissues (El-Banna et al. 2013). The study reported that Crassula argentea infected by16SrII-D phytoplasma group induced morphological and biochemical abnormalities. RAPD molecular marker analysis revealed epigenetic variations between normal and phytoplasma infected plants. Moreover, RAPDD could be utilized for the identification of Crassula genotypes and provide better knowledge of the genetic fingerprinting.

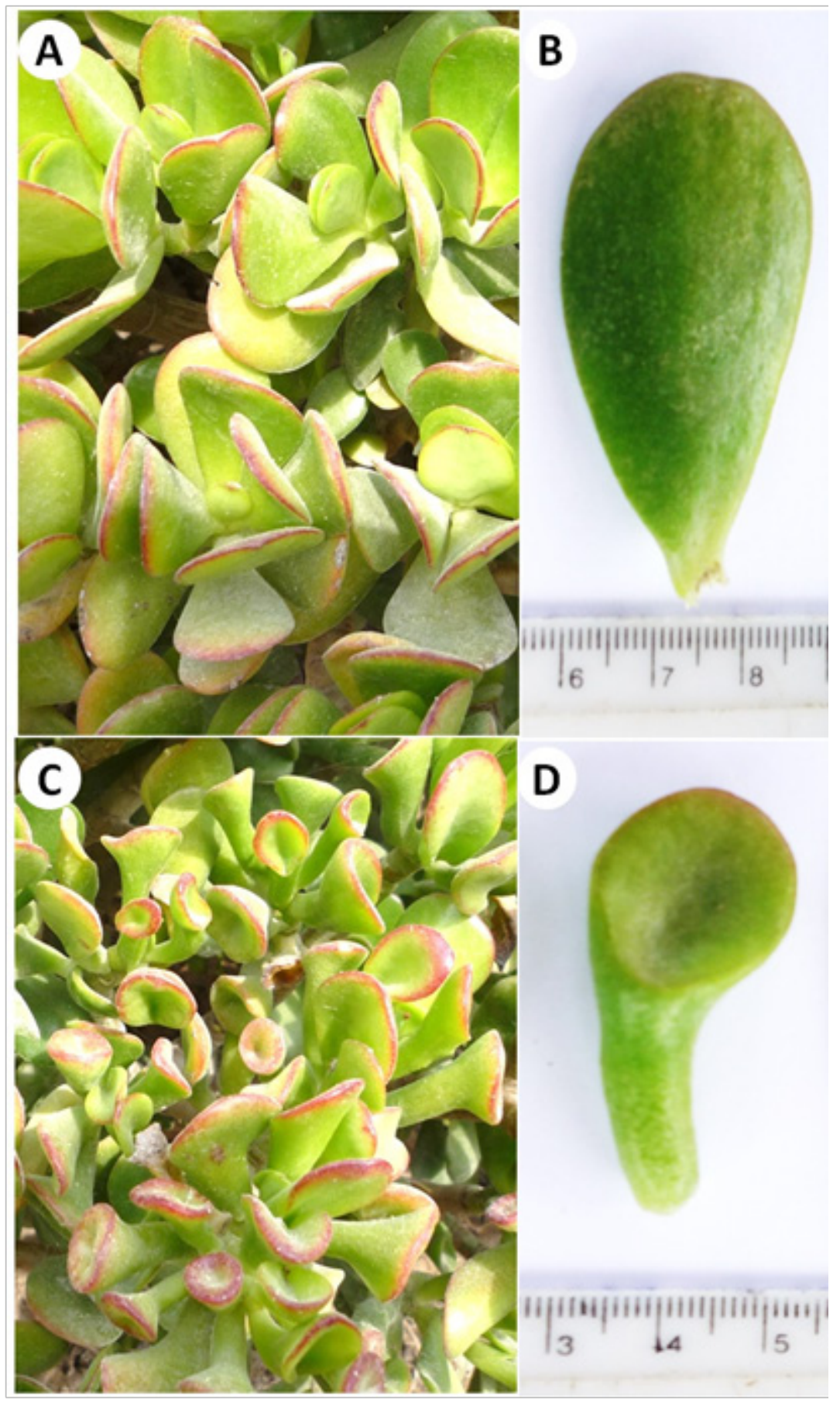

Fig. 1.Phytoplasma-induced fasciation in Crassula argentea A) symptomless plant (normal), B) symptomless leaf shape,C) Phytoplasma infected plant (abnormal), and D) Fasciated leaf showing bell-shape 
TABLE 1. Chemical composition of normal and abnormal plants of Crassula argentea

\begin{tabular}{|c|c|c|c|c|c|c|c|c|c|}
\hline Plant & 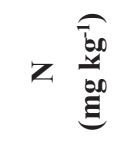 & 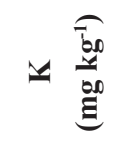 & 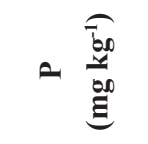 & 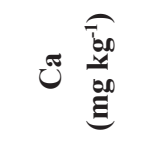 & 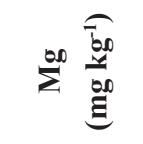 & 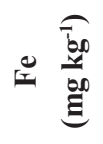 & 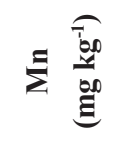 & 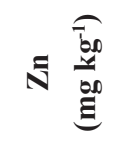 & 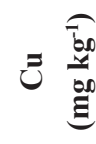 \\
\hline Normal & $9262.5 \mathrm{a}$ & $6525 \mathrm{~b}$ & $1383.38 \mathrm{a}$ & $36500 \mathrm{a}$ & $13680 \mathrm{a}$ & 43.00 & $51.27 \mathrm{a}$ & $91.25 \mathrm{a}$ & $6.43 \mathrm{a}$ \\
\hline Significance & $* *$ & $* *$ & $* *$ & $* *$ & $* *$ & ns & $* *$ & $* *$ & $* *$ \\
\hline
\end{tabular}

Different letters in same column show significant differences among each group of treatments according to Duncan's test at $\mathrm{p} \leq 0.1$.

TABLE 2. Distribution of RAPD markers between the phytoplasma infected and symptomless Crassula argentea plants

\begin{tabular}{ccccc}
\hline Primer name & $\begin{array}{c}\text { Sequences } \\
(\mathbf{5 - 3}-)\end{array}$ & $\begin{array}{c}\text { Total number of } \\
\text { bands }\end{array}$ & $\begin{array}{c}\text { Polymorphic } \\
\text { bands }\end{array}$ & $\begin{array}{c}\text { Polymorphism } \\
\text { (\%) }\end{array}$ \\
\hline Opd12 & CACCGTATCC & 12 & 0 & 0.0 \\
Opq14 & GGACGCTTCA & 10 & 0 & 0.0 \\
Opc04 & CCGCATCTAC & 12 & 4 & 33.3 \\
Opc10 & TGTCTGGGTG & 8 & 3 & 37.5 \\
Opk05 & TCTGTCGAGG & 10 & 2 & 20 \\
Opu05 & TTGGCGGCCT & 15 & 13 & 86.7 \\
& TCGGAGGTTC & & & \\
Total & & 67 & 22 & \\
\hline
\end{tabular}
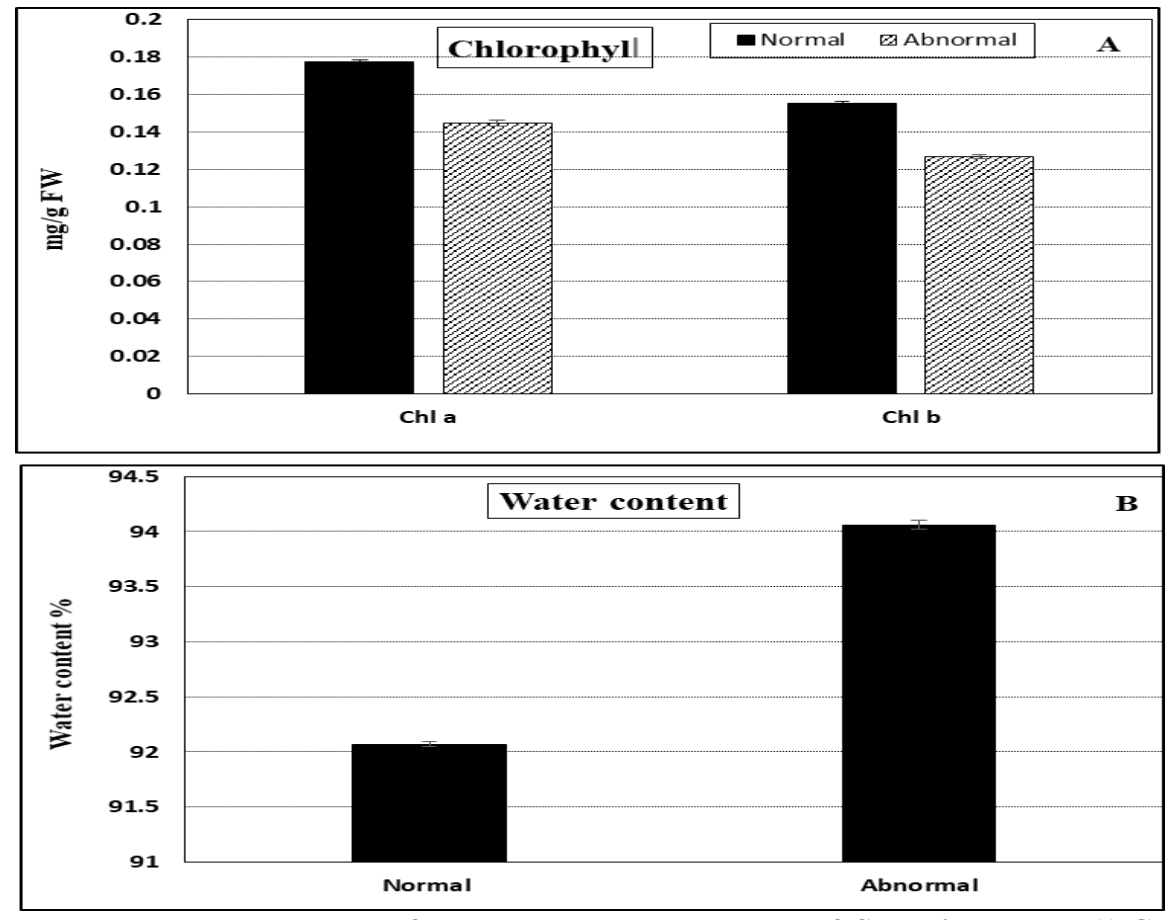

Fig. 2. Chlorophyll and water contents of normal and abnormal plants of Crassula argentea A) Chlorophyll a (Chl a) and chlorophyll b (Chl b); B) water content

Env. Biodiv. Soil Security, Vol. 5 (2021) 


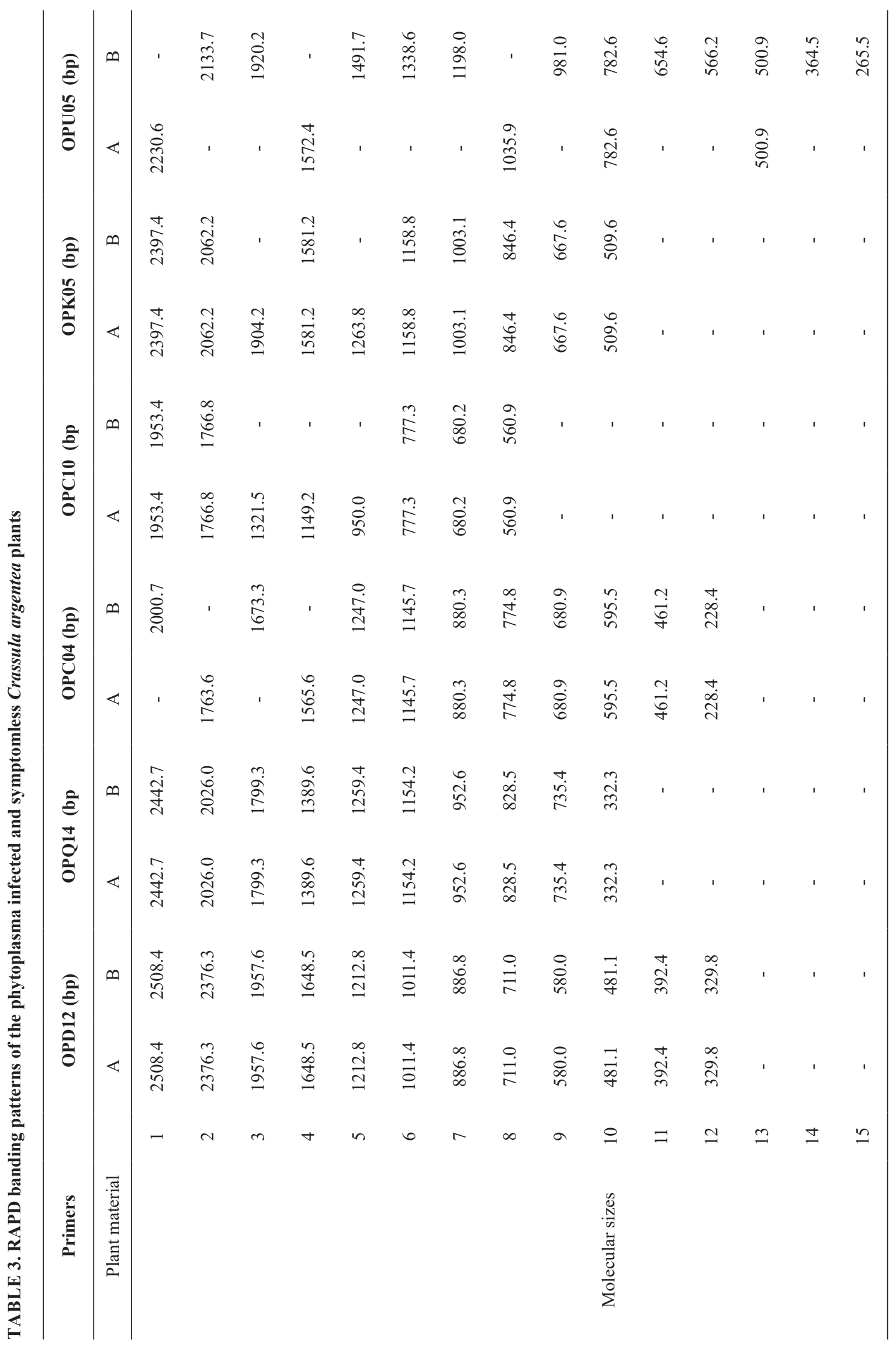

Env. Biodiv. Soil Security, Vol. 5 (2021) 


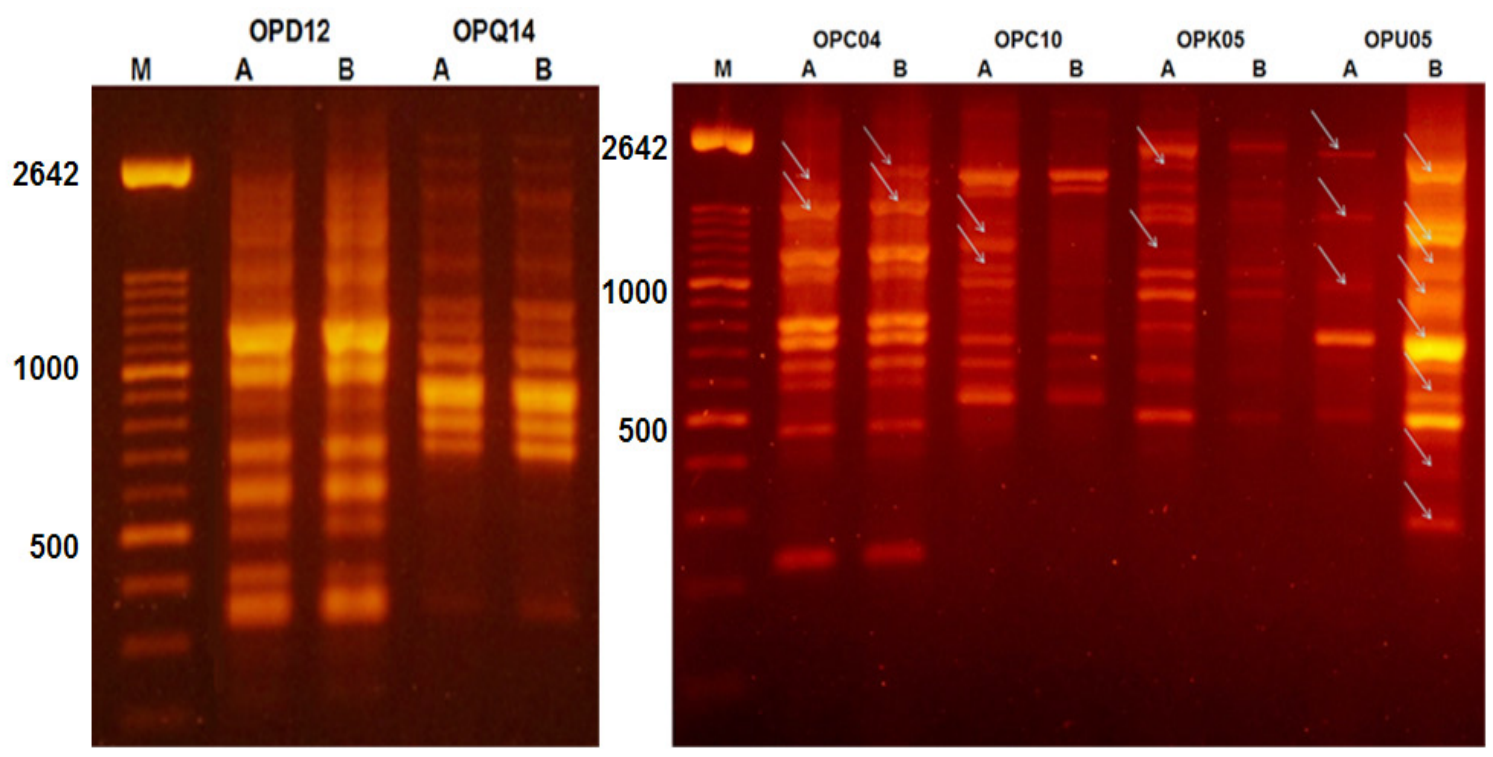

Fig. 3. RAPD profiles of the phytoplasma infected and symptomless Crassula argentea plants A, Symptomless plant (normal); ,B, Phytopasma infected plant; M, DNA marker (100bp)

Previous study on Opuntiacyl indrica showed variations in symptomless and fasciated tissues based on SDS-PAGE protein and randomly amplified polymorphic DNA analysis indicating possible epigenetic mutation of tissues (El-Banna et al. 2013). The study reported that Crassula argentea infected by 16 SrII-D phytoplasma group induced morphological and biochemical abnormalities. RAPD molecular marker analysis revealed epigenetic variations between normal and phytoplasma infected plants. Moreover, RAPDD could be utilized for the identification of Crassula genotypes and provide better knowledge of the genetic fingerprinting.

\section{Conclusion}

Chemical composition of normal plant was higher than abnormal plant except $\mathrm{K}$. In addition; chlorophyll and water contents were higher in normal plants. It is observed that phytoplasma induced variation of Crassula argentea. From that, further studies on phytoplasma infection of succulent and cacti plants are required such as effect of phytoplasma on hormones content and cell structure.

\section{References}

Amtmann A, Troufflard S, Armengaud P (2008). The effect of potassium nutrition on pest and disease resistance in plants. Physiol. Plant., 133, 682-691. doi: $10.1111 / \mathrm{j} .1399-3054.2008 .01075 . x$

Env. Biodiv. Soil Security, Vol. 5 (2021)
Bertaccini A, Calari A, Felker P (2007) Developing a method for phytoplasma identification in cactus pear samples from California. Bulletin of Insectology, 60: $257-258$.

Bertaccini A, Duduk B (2009). Phytoplasma and phytoplasma diseases: a review of recent research. Phytopathologia Mediterranea, 48: 355-378.

Bertaccini A, Duduk B, Paltrinieri S, Contaldo N (2014).Phytoplasmas and phytoplasma diseases: a severe threat toagriculture. American Journal of Plant Sciences, 5: 1763-1788.

Buoso S, Pagliari L, Musetti R, Martini M, Marroni F,Schmidt W,Santi S (2019) CandidatusPhytoplasm asolani'interfereswith the distribution and uptake of iron intomato. BMC Genomics, 20: (703): 1-21. doi. org/10.1186/s12864-019-6062-x

Cai H, Wei W, Davis RE, Chen H, Zhao Y (2008) Genetic diversity among phytoplasmas infecting Opuntia species: virtual RFLP analysis identifies new subgroups in the peanut witches,-broom phytoplasm a group. International Journal of Systematic and Evolutionary Microbiology, 58: 1448-1457.

Cao D, Oard JH (1997) Pedigree and RAPD-based DNA analysis of commercial U.S. rice cultivars. Crop Sci., 37: 1630-1635.

Chang CJ (1977). Histological investigation on phyllody in Catharanthusroseus. M.S. thesis, University of Missouri 
Chemists AA, Horwitz W (1990) Official methods of analysis. Vol. I. 15th ed. AOAC, Arlington, VA.

Dewir YH (2016). Cacti and succulent plant species as phytoplasma hosts: A review. Phytopathogenic Mollicutes 6: 1-9.

Dewir YH, El-Mahrouk ME, Omar AF (2015). Molecular characterization of 16 SrII phytoplasma group and associateddown-regulationof ABA and IAA in Opuntia caracasana. Phytopathogenic Mollicutes, 5: 100-106.

Dewir YH, Omar AF, Hafez YM, El-Mahrouk ME and Mourad RY (2016) Fasciation in Crassula argentea: molecular identification of phytoplasmas and associated antioxidative capacity. Phytoparasitica, 44: $65-74$.

Doyle JJ, Doyle JL (1990) Isolation of plant DNA from fresh tissue. Focus 12, 13-15.

Duduk B, Bertaccini A (2006) Corn with symptoms of reddening: new host of stolbur phytoplasma. Plant Disease, 90: 1313-1319.

Eggli UR (2002) Illustrated handbook of succulent plants, Crassulaceae illustrated handbook of succulent plants. Springer, Berlin

El-Banna AN, El-Nady MF, Dewir YH, El-Mahrouk ME (2013). Stem fasciation in cacti and succulent species - tissue anatomy, protein pattern and RAPD polymorphisms. Acta Biologica Hungarica, 64: 305-318.

Evenhuis B, de Waard PWF (1980). Principles and practices in plant analysis. Soil and Plant Testing and Analysis. FAO Soils Bull. 38:152-163

Fukuoka S, Hosaka K, Kamijima O (1992). Use of random amplified polymorphic DNAs (RAPDs) for identification of rice accessions. Japanese J. Genet., 67: $243-252$

Granata G and Sidoti A (2002). Survey of diseases discovered on Opuntia ficus -indica in producer countries. Acta Horticulturae, 581: 231-237.

Granata G, Paltrinieri S, Botti S, Bertaccini A (2006). Aetiology of Opuntia ficus-indica malformations and stunting disease. Annals of Applied Biology, 149: 317-325.

GRIN (Germplasm Resources Information Network). Crassula ovata(2015). Agricultural Research Service (ARS), United States Department of Agriculture (USDA). Retrieved, 08-10

Hemmati C, Nikooei M, Tahmasebi A, Al-Sadi AM
(2021). Molecular identification and transmission mode of a phytoplasma and its effect on fatty acid composition in Tavernieracuneifolia. Physiological and Molecular Plant Pathology 114, 101628. https://doi.org/10.1016/j.pmpp.2021.101628

Hogenhout SA, Oshima K, Ammar E-D, Kakizawa S, Kingdom HN and Namba S (2008) Phytoplasmas: Bacteria that manipulate plants and insects. Molecular Plant Pathology, 9: 403-423

Isenegger DA, TaylorPJ, FordR, FranzP,Mcgregor GR (2001). DNA fingerprinting and genetic relationships of potato cultivars (Solanumtuberosum L.) commercially grown in Australia. Australian J. Agricultural Res., 52: 911-918.

Ji XL, Gai YP, Zheng CC, Mu Z (2009) Comparative proteomicanalysis provides new insights into mulberry dwarf responses in mulberry (Morus alba L.). Proteomics, 9:5328-5339

Jones JB, Wolf JB, Mills HA (1991) Plant analysis handbook: a practical sampling, preparation, analysis, and interpretation guide. Athens: Micromacro Publishing.

Lee IM (2000) Phytoplasma casts a magic spell that turns the fairpoinsettia into a Christmas showpiece. Plant Health Progress, DOI: 10.1094/PHP-20000914-01-RV.

Li Z-N, Zhang L, Bai Y-B, Liu P, Wu YF (2012). Detection and identification of the elm yellows group phytoplasma associated with Puna chicory flat stem in China. Canadian Journal of Plant Pathology, 34: 34-41.

Mackill DJ (1995) Classifying japonica rice cultivars with RAPD markers. Crop Sci., 35: 889-894.

MacLean AM, Sugio A, Makarova OV, Findlay KC, Grieve VM, Tóth R, Nicolaisen M, Hogenhout SA (2011) Phytoplasma effector SAP54 induces indeterminate leaf-like flower development in Arabidopsis plants. Plant Physiology, 157, 831-841

Moran R, Porath D (1982) Chlorophyll determination in intact tissues using N, N-Dimethyl formamide. Plant Physiol. 69: 1370 - 1381.

Morandini P, Salamini F(2003). Plant biotechnology and breeding: Allied for years to come. Trends in Plant Science, 8:70-75.

Murphy J, Riley JP (1962) A modified single solution method for the determination of phosphate in natural waters. Anal. Chim. Acta, 27:31-36.

Env. Biodiv. Soil Security, Vol. 5 (2021) 
Qian Q, Chen H, Sun ZX, Zhu LH (1996). The study on determining true and false hybrid rice II you 63 using RAPD molecular markers. Chinese J. Rice Sci., 10: $241-242$

Oliveira E, Magalha es PC, Gomide RL, Vasconcelos CA, Souza IRP, Oliveira CM, Cruz I, Schaffert RE (2002). Growth and nutrition of mollicute infected maize. Plant Dis., 86: 945-949.

Omar AF, Dewir YH, El-Mahrouk ME(2014). Molecular identification of phytoplasmas in fasciated cacti and succulent species and associated hormonal perturbation, Journal of Plant Interactions, 9:1, 632-639, DOI: 10.1080/17429145.2014.882421

Omar AF, Emeran AA, Abass JM (2008) Detection of phytoplasma associated with periwinkle virescence in Egypt. Plant Pathol J. 7: 92-97.

Omar AF and Foissac X (2012). Occurrence and incidence ofphytoplasmas of the 16SrII-D subgroup on solanaceous andcucurbit crop in Egypt. European Journal of Plant Pathology,133: 353-360.

Pagliari L, Martini M, Loschi A, Musetti R (2016). Looking inside phytoplasma-infected sieve elements: a combined microscopy approach usingArabidopsis thaliana as a model plant. Micron. 89: 87-97.

Pervaiz ZH, Rabbani MA, Shinwari ZK, Masood MS, Malik SA (2010). Assessment of genetic variability in rice (Oryza sativa L.) germplasm from Pakistan using RAPD markers. Pak. J. Bot., 42: 3369-3376.

Pradit N, Mescher MC, Wang Y,VorsaN, RodriguezSaona C (2019) Phytoplasma Infection of Cranberries Benefits Non-vector Phytophagous Insects. Front. Ecol. Evol., 7: 181.doi: 10.3389/ fevo.2019.00181

Rasool A, Jahan MS, Shazad U, Tariq A, Calica PN (2020) Effect of Phytoplasma Infection on Primary and Secondary Metabolites and Antioxidative Enzyme Activities of Sweet Orange (Citrus sinenses L.). J. Plant Pathol Microbiol, 11 (519): 1-8.doi: 10.35248/2157-7471.20.11.519

Snedecor GW, Cochran WG (1990) Statistical Methods. The $8^{\text {th }}$ edition, Iowa State Univ. Press, Ames.
Spooner DM, McLean KG, Fau-Ramsay KR, Ramsay $G$ (2005) A single domestication for potato based on multi-locus amplifled fragment length. Proc. Natl. Acad. Sci., 102: 14694-1499.

Tanksley SD, Ganal MW, Martin GB(1995). Chromosome landing: a paradigm for map-based gene cloning in plants with large genomes. Trends Genet., 11: 63-68.

USDA (2004). Soil Survey Laboratory Methods Manual. Soil Survey Investigation Report No. 42, Version 4.

Wei W, Cai H, Chen H, Davis RE, Zhao Y (2007) First report of a natural infection of Opuntia sp. by a 'Candidatus Phytoplasma asteris' related phytoplasma in China. Plant Disease, 4: 461.

Weintraub PG, Beanland L (2006). Insect vectors of phytoplasmas. Annual Review of Entomology, 51 $91-111$

Welsh J, McClelland M (1990) Fingerprinting genomes using PCR with arbitrary primers. Nucl. Acids Res., 18: 7213-7218.

Williams JGK, Kubelik AR, Livak KJ, Rafalski JA, Tingey SV (1990) DNA polymorphisms amplified by arbitrary primers are useful as genetic markers Nucl. Acids Res., 18: 6531-6535.

Xue C, Liu Z, Dai L, Bu J, Liu M, Zhao Z, Jiang Z, Gao W, Zhao J (2018). Changinghost photosynthetic, carbohydrate, and energy metabolisms play importantroles in Phytoplasma infection Phytopathology, 108: 1067-77.

Yu, KF, Pauls KP (1992). Optimization of the PCR program for RAPD analysis. Nucl. Acids Res., 20 2606-2606. DOI: 10.1093/nar/20.10.2606

Zafari S, Niknam V, Musetti R, Noorbakhsh SN (2012). Effect of phytoplasma infection on metabolite content and antioxidant enzyme activity in lime (Citrus aurantifolia). Acta Physiol Plant, 34: 561568.

Zak LF, Yáñez MMJ (2006) Presence of phytoplasma in edible cactus, insects, snails, and weeds Proceedings of the $11^{\text {th }}$ international conference on plant pathogenic bacteria. Edinburgh, Scotland. UK, Abstract A-p. 29. 